Vol 3 No 3 (2022) 440-449 P-ISSN 2620-295 E-ISSN 2747-0490 DOI: 1047467/elmal.v3i3.922

\title{
Analisis Manajemen Risiko Pengguna Sewa Guna Usaha (Leasing) di Indonesia
}

\author{
Febby Ayu Syahputri Gurning1, Sonia Ritonga ${ }^{2}$, Ardiyah Meianti³, \\ Maryam Batubara ${ }^{4}$ \\ Fakultas Ekonomi dan Bisnis Islam, Universtias Islam Negeri Sumatera Utara \\ 1 febbyayugurning@gmail.com, 22soniaritonga024@gmail.com, \\ 3ardhiameianti26@gmail.com
}

\begin{abstract}
Leasing or leasing is actually an improvisation ofconventional legal system called leasing. Leasing company business in Indonesia is better known as leasing. Company main activities leasing is engaged in financing for the purposes of capital goods desired by customers. Financing here means if a customer needs capital goods such as heavy equipment, office equipment, cars by renting or buying on credit can be obtained from the leasing company. Leases are actually wider than understanding of lease purchase, because there is a business lease in the form of a finance lease (with option) and operating lease (without option). Rent for business too is one of the high risk avoidance measures that are currently being implemented realized by existing entrepreneurs, so there needs to be more understanding clear on the risks that arise in leasing activities. This study used qualitative research methods. The purpose of this research is to analyze the risk of leasing users, especially in Indonesia.
\end{abstract}

Keywoard : Leasing, risk management

\section{ABSTRACT}

Leasing, kadang-kadang dikenal sebagai leasing, adalah modifikasi dari lembaga hukum tradisional. Perusahaan leasing lebih dikenal dengan istilah leasing di Indonesia. Bisnis utama perusahaan leasing adalah menyediakan pembiayaan untuk kebutuhan barang modal pelanggan. Jika konsumen membutuhkan barang modal seperti alat berat, peralatan kantor, atau mobil, perusahaan leasing dapat menyediakannya untuk disewakan atau dibeli secara kredit. Karena terdapat sewa pembiayaan (dengan hak opsi) dan sewa operasi, definisi sewa sebenarnya lebih besar daripada sewa beli (tanpa hak opsi). Pengusaha eksisting menyadari bahwa leasing merupakan salah satu teknik penghindaran risiko tinggi, oleh karena itu perlu adanya kesadaran yang lebih baik terhadap bahaya yang timbul dalam kegiatan leasing. Metodologi penelitian kualitatif digunakan dalam penelitian ini. Tujuan dari penelitian ini adalah untuk melihat risiko pengguna leasing, khususnya di Indonesia.

Kata kunci : manajemen risiko, leasing 
Vol 3 No 3 (2022) 440-449 P-ISSN 2620-295 E-ISSN 2747-0490 DOI: 1047467/elmal.v3i3.922

\section{PENDAHULUAN}

183 perusahaan terkena dampak leasing atau sewa guna usaha pada April 2020, atau selama awal pandemi Covid-19. Setelah satu tahun, tersisa 171 perusahaan, dengan hanya 167 yang tersisa sekarang. Sebelum mewabah, Otoritas Jasa Keuangan (OJK) menyatakan beberapa pelaku industri keuangan tersebut mengalami kesulitan. Apalagi bagi yang belum bisa memenuhi syarat modal minimal Rp 100 miliar. Perusahaan yang tersisa termasuk mereka yang kesulitan menemukan mitra bisnis yang cocok, memiliki kualitas pinjaman yang lebih rendah, mengabaikan masalah tata kelola, atau berencana untuk menutup pintu mereka jauh sebelum Covid-19 tiba di negara ini, atau tidak mencapai ekuitas minimum untuk membayar- rasio modal naik 50\%. Setiap perusahaan pasti akan menghadapi berbagai bahaya. Setiap kegiatan ekonomi dan perusahaan tidak dapat dipisahkan dari risiko dalam berbagai bentuk dan tingkatan.

Perusahaan pembiayaan, sebagai salah satu tumpuan sektor keuangan dalam memberikan jasa keuangan di bidang pembiayaan dan perkreditan, jelas membutuhkan manajemen, pengendalian, dan distribusi risiko yang efektif. Alhasil, pelaku bisnis leasing harus mampu mengelola risiko yang dihadapi dengan baik. Salah satu komponen terpenting dalam menjalankan perusahaan keuangan adalah manajemen risiko. Manajemen risiko akan menjaga dan mempertahankan perusahaan dari kerugian yang mungkin timbul sebagai akibat dari berbagai aktivitas perusahaan, serta menjaga risiko sesuai dengan pedoman yang telah ditetapkan.

\section{TINJAUAN LITERATUR}

\section{a. Manajemen Risiko}

Manajemen risiko digambarkan sebagai metode sistematis untuk mengatasi semua kejadian yang menyebabkan kerugian. Proses keuangan, pengukuran, dan pengendalian risiko perusahaan yang mengancam aset dan pendapatan suatu proyek atau proyek yang dapat menyebabkan kerusakan atau kerugian perusahaan disebut sebagai manajemen risiko. Manajemen risiko berusaha untuk mengurangi ancaman ini sehingga kita bisa mendapatkan hasil terbaik (Clough \& Sears, 2000). Kegiatan-kegiatan berikut dapat dilakukan oleh organisasi untuk mengatasi risiko :

- bahaya (penghindaran risiko)

- Mitigasi risiko (risk reduction) dapat dilakukan dengan menurunkan kemungkinan atau dampak suatu peristiwa. 
Vol 3 No 3 (2022) 440-449 P-ISSN 2620-295 E-ISSN 2747-0490 DOI: 1047467/elmal.v3i3.922

- Transfer risiko ke pihak ketiga (risk sharing)

- Bersedia mengambil risiko (accepting risk)

\section{b. Pengertian Leasing}

Perjanjian leasing adalah kontrak antara lessor dan lessee untuk menyewakan barang-barang modal tertentu yang telah dipilih atau ditentukan oleh lessee. Lessor memiliki hak atas kepemilikan barang modal, sedangkan lessee hanya dapat menggunakannya jika dia membayar uang pengiriman dalam jangka waktu tertentu (McGugan \& Caves, 1974).

Fungsi leasing hampir sama dengan fungsi bank, yaitu sebagai sumber pembiayaan jangka menengah (dari satu tahun sampai lima tahun). Sewa telah menawarkan cara baru untuk membeli barang modal dan modal kerja yang tumbuh dalam perekonomian nasional. Tidak ada undang-undang eksplisit yang mengatur tentang leasing saat ini; namun, praktik leasing telah berkembang dengan cepat, yang memerlukan kebutuhan akan norma hukum yang jelas dan definitif (McGugan \& Caves, 1974)

Ada tiga pihak kunci dalam leasing, menurut (Riyanto, 1995):

- Lessor adalah perusahaan leasing atau, dalam situasi ini, pihak yang memiliki hak kepemilikan atas barang.

- Lesse adalah korporasi atau entitas yang menggunakan produk dan mungkin memiliki hak opsi pada akhir kontrak.

- Pemasok adalah orang yang disewa.

\section{c. Teknik - Teknik Pembiayaan Leasing}

Jenis transaksi leasing, yang secara garis besar dapat diklasifikasikan menjadi dua jenis, mengungkapkan teknik leasing finance:

\section{Finance Lease}

Sewa pembiayaan adalah jenis pembiayaan yang melibatkan lessor yang menawarkan opsi kepada lessee pada akhir periode sewa. Sewa pembiayaan dapat diklasifikasikan ke dalam jenis transaksi berikut:

a. Sewa dengan Pembiayaan Langsung

Transaksi leasing dalam bentuk direct lease, disebut juga true-lease atau disingkat direct lease, adalah jenis transaksi leasing dimana lessor membeli barang atas permintaan lessee dan sekaligus menyewakannya kepada lessee, atau dapat dikatakan sebagai bentuk dari penyewa yang bersangkutan. 
Vol 3 No 3 (2022) 440-449 P-ISSN 2620-295 E-ISSN 2747-0490 DOI: 1047467/elmal.v3i3.922

\section{b. Sewa Kembali dan Jual}

Pada prinsipnya, transaksi leasing adalah transaksi di mana lessee menjual barang modal kepada lessor dan kemudian mengadakan perjanjian sewa untuk komoditas tersebut.

c. Sewa Sindikasi

Sewa sindikasi adalah salah satu di mana objek leasing dibiayai oleh banyak lessor. Sewa sindikasi muncul ketika lessor tidak menawarkan atau tidak memiliki sumber daya untuk menutup kesepakatan leasing dengan nilai yang cukup untuk kebutuhan lessee.

\section{d. Leverage Lease}

Lease Leverage adalah jenis sewa pembiayaan di mana, selain lessor dan lessee, kreditur jangka panjang terlibat dalam pembiayaan sewa. Lessor hanya bertanggung jawab atas sebagian kecil dari pembiayaan, sedangkan kreditur bertanggung jawab untuk sebagian besar. Sesuai dengan jumlah pembiayaan, lessor langsung bertanggung jawab kepada kreditur.

d. Menyewa Lintas Batas

Sewa lintas batas adalah transaksi yang terjadi di luar batas negara. Karena lessor dan lessee sama-sama berbasis di negara yang berbeda, leasing semacam ini kadang-kadang disebut sebagai leasing internasional.

\section{METODE PENELITIAN}

Penelitian ini menggunakan data kualitatif. Reduksi data digunakan sebagai strategi analisis data dalam penelitian ini. Karena begitu banyak informasi yang dikumpulkan di lapangan, maka harus dicatat dengan cermat.

\section{HASIL PENELITIAN DAN PEMBAHASAN}

\section{a. Hak dan Kewajiban Pengguna Sewa Guna Usaha}

Hubungan antara hak dan kewajiban pengguna sewa guna usaha saling berkesinambungan dalam menjalankan hubungan hukum; Sunaryo membagi hak dan kewajiban para pihak berdasarkan hubungan hukum, antara lain:

\section{1) Hak dan Kewajiban Lessor :}

a) Menerima penyerahan langsung dari pemasok. 
Vol 3 No 3 (2022) 440-449 P-ISSN 2620-295 E-ISSN 2747-0490 DOI: $1047467 /$ elmal.v3i3.922

b) Menerima biaya jasa dari Penyewa dalam bentuk pembayaran angsuran secara berkala selama masa sewa, yang sepenuhnya mencakup pengembalian jumlah yang didanai ditambah bunga.

c) Membayar penyedia secara penuh untuk barang-barang modal yang dibutuhkan oleh Penyewa.

d) Memberikan pembiayaan kepada Penyewa dalam bentuk barang modal.

e) Membayar pemeliharaan, kerusakan, pajak, dan kehilangan pemasok.

\section{2) Hak dan kewajiban penyewa meliputi :}

a) Menerima pembiayaan barang modal.

b) Menerima barang modal langsung dari vendor.

c) Membeli barang modal bernilai sisa atau memperpanjang masa sewa.

d) Memeriksa barang modal yang telah dipasok pemasok, menandatangani kuitansi dan surat perintah pembayaran, kemudian menyerahkannya kepada pemasok.

e) Membayar Lessor neraca pembayaran secara teratur.

f) Pemeliharaan, pajak, dan pertanggungan asuransi sudah termasuk.

\section{3) Hak dan Kewajiban Pemasok}

a) Menerima pembayaran lengkap dari Lessor untuk barang modal yang dibeli.

b) Produk modal disampaikan secara langsung.

Pemasok berhak menerima pembayaran penuh dari lessor atas pembelian langsung barang modal yang dibutuhkan lessee dalam transaksi leasing. Dalam sewa operasi, lessee harus memasok barang modal langsung kepada lessor, sedangkan dalam sewa pembiayaan, lessee harus menyerahkan produk langsung kepada lessee dalam keadaan sehat. Dalam perjanjian leasing dapat dicapai kesepakatan antara lessee dan lessor dalam hal pengaturan jumlah dan jumlah angsuran sesuai dengan kemampuan lessee.

\section{b. Manajemen Risiko Pengguna Sewa Indonesia}

Efektivitas sistem manajemen risiko dan kecukupan pengendalian internal memungkinkan manajemen memperoleh informasi terkini dan akurat jika terjadi pelanggaran atau ketidakpatuhan terhadap proses, yang kemudian dapat digunakan untuk mengambil tindakan mitigasi risiko. 
Vol 3 No 3 (2022) 440-449 P-ISSN 2620-295 E-ISSN 2747-0490 DOI: 1047467/elmal.v3i3.922

Kualitas portofolio pinjaman, yang berada dalam batasan parameter yang ditentukan, menentukan keberhasilan mekanisme manajemen risiko terhadap aset leasing yang berisiko. Untuk organisasi leasing, setidaknya ada tiga (tiga) bentuk dasar risiko:

- Resiko pendanaan dan likuiditas

- Resiko kredit

- Resiko operasional

\section{Resiko Pendanaan dan Likuiditas}

Ekspansi Perseroan bergantung pada kas dari fasilitas perbankan dan sumber lain untuk transaksi pembiayaan baru. Perusahaan leasing harus "lindung nilai" portofolio sumber dana yang tunduk pada volatilitas suku bunga dan nilai tukar mata uang asing ketika mengelola uang. Sebagian dana tersebut dihimpun piutang atau disalurkan untuk mengurangi risiko likuiditas yang disebabkan oleh perbedaan tempo investasi dan sumber dana. Sementara piutang pembiayaan tidak dijual, saham Perusahaan menyediakan sebagian besar modal.

\section{Resiko Kredit}

Tujuan dari penetapan kebijakan kredit adalah untuk meminimalkan resiko kredit atas fasilitas yang diberikan kepada konsumen, antara lain dengan melakukan diversifikasi pada portofolio investasi, dan fokus kepada pembiayaan peralatan yang mudah dijual kembali di pasar sekunder. Kebijakan tersebut juga menetapkan jumlah maksimum pemberian kredit kepada nasabah beserta afiliasinya, menetapkan jumlah otorisasi persetujuan kredit dari pimpinan cabang dan anggota komite kredit, menetapkan rasio pembiayaan terhadap nilai aset yang dibiayai, dan menutup asuransi atas peralatan yang dibiayai melalui perusahaanperusahaan asuransi yang mempunyai reputasi baik. Pengawasan geografis, jenis dan merek peralatan, serta bentuk produk pembiayaan seperti pembiayaan konsumen, leasing, dan lain-lain merupakan contoh diversifikasi portofolio pembiayaan.

a) Diversifikasi dalam hal geografi

Portofolio harus didistribusikan ke seluruh Indonesia. Distribusi portofolio terbesar terdapat di pulau Sumatera, disusul Kalimantan, Jawa \& Bali, dan Sulawesi. Diversifikasi ini membantu perusahaan leasing mengelola penyebaran risiko di beberapa area sebagai akibat 


\section{Vol 3 No 3 (2022) 440-449 P-ISSN 2620-295 E-ISSN 2747-0490 DOI: $1047467 /$ elmal.v3i3.922}

dari bencana alam seperti banjir, gempa bumi, gagal panen, dan bencana alam lainnya.

b) Diversifikasi Merek dan Jenis

Hampir semua pembiayaan kendaraan konsumen adalah untuk merek Jepang, yang memiliki nilai jual kembali yang tinggi dan diminati di pasar sekunder. Portofolio sewa dibagi antara tiga merek terkenal: Komatsu, Caterpillar, dan Hitachi, terutama dalam pembiayaan alat berat. Mayoritas pelanggan adalah pelanggan Komatsu. Di pasar sekunder, ketiga merek tersebut memiliki nilai jual yang kuat.

c) Diversifikasi Jenis

Kendaraan komersial merupakan mayoritas kendaraan yang dibiayai (non sedan). Kendaraan komersial adalah kendaraan yang digunakan untuk menghasilkan pendapatan dan biasanya digunakan untuk bisnis.

d) Diversifikasi Sektor

Portofolio leasing dalam leasing harus merata di 8 (delapan) sektor utama, mulai dari persewaan peralatan, pertambangan, pulp dan kertas, industri pengolahan kayu dan kayu, transportasi air dan lain-lain, kontraktor umum dan lain-lain.

e) Berkonsentrasi pada leasing peralatan yang banyak digunakan dan memiliki risiko rendah.

Sebagian besar piutang usaha merupakan pembiayaan aset berupa alat-alat berat yang dapat digunakan untuk kegiatan di berbagai industri, seperti excavator, bulldozer, motor grader, dan alat berat lainnya, serta alat transportasi dan kelautan seperti kapal tunda. perahu dan tongkang.

f) Hubungan Transaksional Dengan Pihak Berelasi

Kecuali untuk pembiayaan karyawan, perusahaan leasing tidak boleh memiliki portofolio besar dengan perusahaan yang memiliki hubungan khusus.

\section{Resiko Operasional}

Perusahaan leasing harus menerapkan sistem komputerisasi baru yang disebut "E-Loan" di semua kantor cabang untuk mengurangi risiko operasional yang disebabkan oleh proses internal, kesalahan manusia, dan 


\section{Vol 3 No 3 (2022) 440-449 P-ISSN 2620-295 E-ISSN 2747-0490 DOI: $1047467 /$ elmal.v3i3.922}

kesalahan sistem. E-Loan merupakan sistem dengan platform website yang dirancang untuk mempercepat proses pengelolaan data guna meningkatkan pengawasan peminjaman.

\section{KESIMPULAN}

\section{Kesimpulan}

Beberapa kesulitan yang dihadapi oleh para pihak dalam perjanjian sewa adalah sebagai berikut:

f) Kepemilikan barang akan dialihkan hanya setelah kewajiban penyewa telah dipenuhi dan hak opsi telah dilaksanakan.

g) Jika ketentuan seperti itu ada dalam perjanjian sewa, konsekuensinya berat.

h) Barang modal penyewa tidak dapat dijadikan jaminan untuk memperoleh kredit.

i) Bahaya yang berhubungan dengan peralatan atau barang modal itu sendiri. Adanya kegagalan lessee untuk menjual, menyewakan, atau menggadaikan kepada pihak leasing lainnya.

Untuk menjawab permasalahan di atas, maka perjanjian sewa guna usaha sebagai salah satu jenis lembaga pembiayaan juga harus melakukan analisis pembiayaan secara menyeluruh. Sebelum memberikan pembiayaan, lessor melakukan analisis pembiayaan untuk memastikan bahwa lessee dapat dipercaya. Analisis pembiayaan memperhitungkan latar belakang penyewa atau pelanggan atau perusahaan, proyek bisnis, dan faktor lainnya. Tujuan dari analisis ini adalah untuk meyakinkan lessor bahwa pembiayaan yang diberikan benar-benar aman. Prinsip-prinsip 5C yang meliputi character, capacity, capital, conditions, dan collateral, dikenal di tingkat operasional bank dalam pemberian fasilitas kredit atau pembiayaan.

\section{Saran}

Berdasarkan hal-hal tersebut di atas, direkomendasikan agar dicantumkan klausula dan akta notaris untuk menghindari interaksi atau perselisihan antara para pihak, yaitu lessee dan lessor. Untuk menghindari risiko dalam perjanjian sewa guna usaha, analisis pembiayaan yang tepat dilakukan dengan melibatkan pihak ketiga dalam asuransi pihak ketiga untuk mencegah atau menjamin risiko baik dari lessee maupun lessor. 
Vol 3 No 3 (2022) 440-449 P-ISSN 2620-295 E-ISSN 2747-0490 DOI: 1047467/elmal.v3i3.922

\section{DAFTAR PUSTAKA}

Achmad Anwari, 2017, Leasing di Indonesia, Jakarta: Ghalia Indonesia

Andasasmita, Komar. 2018. Leasing (Teori dan Praktek). Cetakan I Ikatan Notaris Indonesia, Komisariat daerah Jawa Barat, Bandung.

Anwari, Achmad. 2019. Leasing di Indonesia. Ghalia Indonesia, Jakarta.

Ayat, Safri. Manajemen Risiko. Jakarta: Gema Insani Akastri. 2003.

Fadhilah, N. (2019). Mekanisme Sewa Guna Menurut Perspektif Islam \& Perbandingannya. Jurnal Qiema (Qomaruddin Islamic Economics Magazine), 5(2), 135-149.

Fuadi, F. (2020). Bank dan Lembaga Keuangan Non Bank (Teori dan Aplikasinya). Indramayu: Penerbit Adab.

Handiman, A. A. (2019). Bank dan Lembaga Keuangan Bukan Bank. Jakarta: PT. Indeks

https://m.bisnis.com/amp/read/20210804/89/1425873/jumlah-pemainleasing-menciut-kini-tinggal-167-perusahaan-adaapa\#aoh=16399259404476\&referrer=https\%3A\%2F\%2Fwww.google.co $\underline{\mathrm{m} \& \mathrm{amp} \mathrm{tf}=\text { Dari } \% 20 \% 251 \% 24 \mathrm{~s}}$

https://m.liputan6.com/bisnis/read/4677349/marak-debitur-leasing-nakalberikut-kenali-modusnya

https://www.kreditpedia.net/manajemen-risiko-pada-industri-multifinanceperusahaan-pembiayaan/

Huda, Nurul dan Mohammad Heyikal.2010. Lembaga Keuangan Islam. Jakarta: Kencana.

Kasmiir, SE, MM, BANK \& LEMBAGA KEUANGAN LAINNYA, Jakarta, Rajawali Press, 2002.

Martono. 2002. BANK \& LEMBAGA KEUANGAN LAIN. Yogakarta: Ekonosia.

Maryvin K. Lewiss dan Latifa M Alqaoud, Perbankan Syariah : Prinsip, Praktik, Prospek, Jakarta, Serambi, 2013. 
Vol 3 No 3 (2022) 440-449 P-ISSN 2620-295 E-ISSN 2747-0490 DOI: $1047467 /$ elmal.v3i3.922

Muhammad, Sistem dan Prosedur Operasional Bank Syariah, Yogyakarta, UII Press, 2001.

Saefuddin, S. (2019). Leasing Dalam Keuangan Syariah. Az Zarqa' : Jurnal Hukum Bisnis Islam, 11(2).

Samsudin, dkk, 2017, Paper Manajemen Risiko, Universitas Indonesia

Suyyatno, Thomas, “ Kelembagaan Perbankan”. Jakarta: PT. Gramedia Pustaka Utama, 1999.

Y. Sr i Susilo, dkk, "Bank dan Lembaga Keuangan Lain", Jakarta : Penerbit Salemba Empat, 2002. 